\title{
Fish faunal and habitat analyses using trawls, camera sleds and submersibles in benthic deep-sea habitats off central California
}

\author{
Gregor M. CAILLIET ${ }^{a^{*}}$, Allen H. ANDREWS ${ }^{a}$, W. Waldo WAKEFIELD ${ }^{\text {b }}$ \\ Guillermo MORENO ${ }^{\text {a }}$, Kevin L. RHODES ${ }^{\mathrm{c}}$ \\ ${ }^{a}$ Moss Landing Marine Laboratories (MLML) P.O. Box 450, Moss Landing, California 95039-0450, USA \\ ${ }^{\mathrm{b}}$ Northwest Fisheries Science Centre, Hatfield Marine Science Centre, Newport, Oregon 97365, USA \\ ${ }^{c}$ Department of Ecology and Biodiversity, University of Hong Kong, Hong Kong
}

Revised 31 March 1999; accepted 6 May 1999

\begin{abstract}
Beam trawl, camera sled and submersible data from $2000-3300 \mathrm{~m}$ off central California produced similar fish faunal composition, but different density estimates. All species caught in trawls were observed in camera-sled and submersible observations. However, some rare species that were observed were not caught in trawls. The fish fauna was dominated by the families Macrouridae, Zoarcidae, Moridae, and Rajidae. Fishes both trawled and observed were the macrourids Coryphaenoides armatus, C. filifer and C. leptolepis; the zoarcids Bothrocara spp., Pachycara lepinium and Lycenchelys spp.; the morid Antimora microlepis; the rajid Bathyraja trachura, the ophidiid Spectrunculus grandis, and the liparidid Careproctus ovigerum. One unidentified liparidid (Paraliparis sp.) and two unidentified Lycenchelys spp. were trawled and may have been seen but also could not be identified to species from photographs. Observed only in photographs were the liparidids Paraliparis rosaceus and Careproctus melanurus, synodontid Bathysaurus mollis, and notocanthid Notacanthus chemnitzii. These three techniques differed in their ability to provide specimens for accurate identification, counts, and later life history (feeding habit, age and growth, and reproduction) studies, and to provide information on dispersion, habitat utilization, behavior and interactions. Accurate density estimates were undoubtedly hampered by trawl and camera sled avoidance, escape, and uncertainties concerning the area trawled. Camera sleds produced higher (and perhaps better) estimates of density. Submersible observations from the DSV Alvin produced a similar species list but little additional, quantitative information. Both visual techniques allowed habitat characterization, but no strong faunal associations with habitat types were observed. (ㅇ 1999 Ifremer / CNRS / IRD / Éditions scientifiques et médicales Elsevier SAS
\end{abstract}

deep-sea / fishes / habitat / sampling / submersibles

Résumé - Chalutage, photographie et observation par submersible des poissons benthiques dans les habitats profonds au large de la Californie. La faune des poissons a été étudiée entre 2000 et $3300 \mathrm{~m}$ de profondeur au large de la Californie centrale, par trois méthodes : chalutage, photographie et observation à partir d'un submersible. Les compositions faunistiques obtenues sont similaires, mais les densités diffèrent. Toutes les espèces prélevées au chalut ont été observées sur photographie et par submersible ; en revanche, quelques espèces observées sont absentes du chalut. Les résultats montrent la dominance des familles Macrouridae, Zoarcidae, Moridae et Rajidae. Poissons chalutés et observés : macrouridés Coryphaenoides armatus, C. filifer et C. leptolepis ; zoarcidés Bothrocara spp., Pachycara lepinium et Lycenchelys spp. ; moridé Antimora microlepis ; rajidé Bathyraja trachura, ophidiidé Spectrunculus grandis et liparididé Careproctus ovigerum. Poissons chalutés qui n'ont pu être identifiés sur les photographies : un liparididé (Paraliparis sp.) et deux Lycenchelys spp. Poissons observés uniquement sur les photographies : liparididés Paraliparis rosaceus et Care-

\footnotetext{
${ }^{*}$ Correspondence and reprints: caillet $@$ mlml.calstate.edu
} 
proctus melanurus, synodontidé Bathysaurus mollis et notocanthidé Notacanthus chemnitzil. Les trois techniques diffèrent par la possibilité de disposer de specimens pour l'identification, les comptages et l'étude des conditions de vie (alimentation, âge et croissance, reproduction) et par les informations qu'elles fournissent sur la dispersion, l'habitat, le comportement et les interactions. Les estimations précises de la densité sont certainement biaisées par ce qui échappe au chalut ou au balayage photographique, par la fuite des poissons et par les incertitudes sur la surface chalutée. Le balayage photographique donne les valeurs de densité les plus fortes (et probablement les meilleures). Les observations par le submersible Alvin donnent une liste similaire des espèces et ajoutent peu d'information quantitative. Les deux techniques visuelles ont permis de caractériser l'habitat, mais il n'a pas été observé de forte association entre la faune et le type d'habitat. (C) 1999 Ifremer / CNRS / IRD / Éditions scientifiques et médicales Elsevier SAS

\section{benthos / poisson / habitat / chalutage / submersible}

\section{INTRODUCTION}

Because deep-sea habitats are remote and usually occur considerable distances offshore, sampling deep-sea benthic fishes is a very difficult, time-consuming, and therefore expensive, task. Such surveys require large ships, with huge amounts of cable, a strong winch and A-frame, and specialized sampling gear, including trawls and camera sleds. The time required to deploy and retrieve this gear to such great depths is lengthy. Slow tows are necessary so the gear remains on the bottom and samples the organisms adequately. For trawls, accurate density estimates rely on knowing the actual time the gear was sampling the bottom. In addition, problems of avoidance, escape, and gear fouling can affect trawling efficiency, while trauma to fish from pressure and temperature changes during retrieval to the surface can influence specimen condition and therefore taxonomic identification. Camera sleds provide detailed observations of both the fishes and their habitat, but no physical samples can be taken. However, complete taxonomic identification from photographs or videos can be difficult or impossible. Submersibles provide the same opportunities as the camera sled, but can also provide sample collection and better selection of transects. It is therefore valuable to use more than one technique concurrently, such as cameras mounted on trawls $[64,71]$.

Despite these sampling difficulties, patterns in distribution and abundance of deep-demersal fishes have been characterized [32, 52]. Some authors have used baited traps [37], while others have taken a series of remote deep-sea trawl samples and attempted to characterize the fauna from them $[5,12,22,41,49,51,58,68]$. Others have laken a more direct approach of sampling by observing the fauna using submersibles, underwater camera systems, or remotely operated vehicles (ROVs) in an area to characterize the fauna $[14,17,20,34,45,64,65]$ and sometimes to predict the influence of certain perturbances, such as waste dumping $[15,19,28,38]$. However. few have directly compared two or more very different techniques in the same place and time $[64,70,73]$.

Even if adequate faunal samples can be taken in deep-sea habitats, the ability to characterize the physical nature of these habitats differs among techniques. For example, trawling simply produces specimens of organisms, occasionally bringing a piece of the associated habitat to the surface. Techniques such as camera sleds and submersibles provide visual images and direct observations, in addition to actual sampling, of the habitats in which different species live.

It is thus important to develop efficient tools to sample and study both the deep-sea fish fauna and their associated abiotic and biotic habitats. In this study we used a dedicated beam trawl and camera sled survey, along with additional beam trawl samples and submersible observations in different locations and seasons at the same depths, to comparatively characterize the fish fauna at three different deep-sea sites. The ability to do deep surveys off the coast of central California is enhanced by the close proximity of deep-sea habitats to the shore, both in the form of submarine canyons and a narrow continental shelf $[30,31]$.

\section{METHODS}

Our main objective was to characterize the benthic fishes and macroinvertebrates $[55,56]$ occurring at the U.S. Navy Ucean Disposal Site (NODS) west of the Farallon Islands and 39 miles $(65.8 \mathrm{~km})$ west of the Golden Gate Bridge (figure 1: Farallon Site), in depths ranging from approximately 2000 to $3300 \mathrm{~m}$. During this survey, we uscd four techniques (trap, otter and beam trawl, and camera sleds) to sample demersal fishes at the study site. 


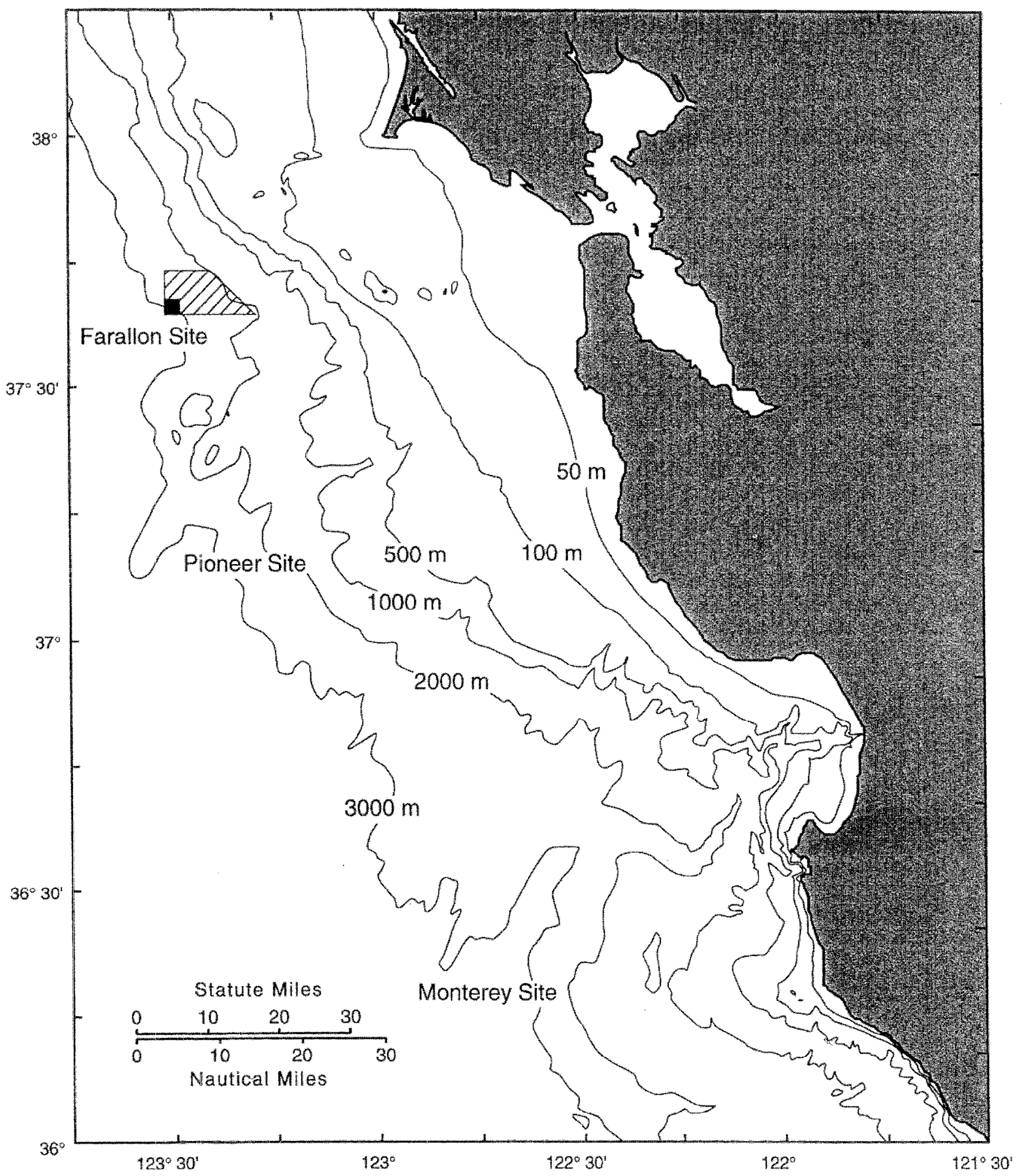

Figure 1. General location and bathymetry of three sites in our study area along the central California coast from off San Francisco to the Monterey Bay region. The northernmost trapezoid (Farallon Site) is within the Navy Ocean Study Area (NOSA), and includes the former Chemical Munitions Dumping Area (CMDA) and the U.S. Navy Ocean Disposal Site (NODS), a smaller $2^{\prime}$ latitude by $2^{\prime}$ longitude area in the southwest corner. For comparisons, we also sampled two sites to the south at similar deptlıs, one ıear Pioneer Canyon (Pioneer Site) and the other outside of Monterey Submarine Canyon (Monterey Site). 
For comparative purposes, we sampled two other sites using similar techniques at a different time of year. This report thus results from a combination of data from several cruises, all intended to sample the deep-sea fish fauna and habitats off central California ([13] for cruise and sample details). It must be noted that such an opportunistic approach with relatively small' sample sizes is often required to study the deep sea due to high costs and harsh oceanographic conditions.

An initial survey was attempted with strings of traps (black cod, shrimp and hagfish) set in May, 1991. Due to inclement weather and sea state conditions, only one set was retrieved three months later. All 12 fish captured by the few traps recovered were the zoarcid, Pachycara lepinium, and the results of this survey will not be discussed further.

Beam and otter trawl samples, and camera sled photographs were taken during July 1991 with the R.V. Wecoma. The frame of the beam trawl had a mouth width of $2.1 \mathrm{~m}$, height of $0.8 \mathrm{~m}$ and a bag length of $6.7 \mathrm{~m}$, constructed of $3.8 \mathrm{~cm}$ stretch mesh seine twine treated with a black net preservative, and fished with a $12.5 \mathrm{~m}$ bridle attached to a single warp. The otter trawl was a semi-balloon net with a $12.5 \mathrm{~m}$ headrope, a $15.2 \mathrm{~m}$ footrope, constructed of $3.8 \mathrm{~cm}$ stretch mesh in the wings, body and codend, and $1.3 \mathrm{~cm}$ stretch mesh codend liner, and fished with a $12.5 \mathrm{~m}$ bridle, weighted aluminum doors and attached to a single warp. A total of 16 trawls was taken over the four day sampling period, of which 12 were beam and 4 otter trawls. All 12 beam trawls were successful at making contact with the bottom and came up containing organisms. One successful beam trawl sample had to be jettisoned with the net because it included a radioactive object. Two of the otter trawls successfully returned samples; the other two were badly twisted.

The beam trawl deployment technique was the same for all tows. A deep-water glass float was attached to the towing cable about 5-7 m ahead of the beam, with another float attached $20 \mathrm{~m}$ ahead of the first. A Benthos ${ }^{\circledR}$ pinger was attached to the cable $70 \mathrm{~m}$ ahead of the beam to monitor bottom contact and an on-board Precision Depth Recorder (PDR) trace was used to record the depth that the trawl sampled. When the pinger trace on the PDR was within $25 \mathrm{~m}$ of the bottom, the winch was slopped and the beam trawl was assumed to be on the bottom. The trawls were kept on the bottom for 30 to $50 \mathrm{~min}$. Any change in depth during the course of the trawl was compensated for by hauling in or letting out more cable to keep the pinger and bottom traces on the PDR at a $25 \mathrm{~m}$ interval, and therefore maintain the net on the bottom. The ratio of warp (length of cable out) to depth for all beam trawls was between 1.4 and 1.5. From this ratio, it was possible to calculate an estimate of the distance of the trawl behind the vessel. The position of the net on the bottom, depth, amount of line out, and tension on the cable were recorded for each trawl. All positions were based on the ship's GPS system.

Fish densities were calculated only for beam trawls because there were few otter trawls taken and they seemed to fish unreliably. The area covered by a beam trawl was calculated using the ship's distance covered during bottom contact multiplied by the $2.1 \mathrm{~m}$ trawl opening. All densities were calculated as number of fish per hectare $\left(10000 \mathrm{~m}^{2}\right)$.

All fish specimens collected were immediately rough sorted into taxa, usually to family or genus. Color photographs were taken of representatives of all taxa. Specimens were either frozen or preserved in $10 \%$ buffered formalin and placed into labeled containers. When further studied at the shore laboratory, they were either changed into isopropyl alcohol or defrosted, then preserved in $10 \%$ formalin, followed by $50 \%$ isopropyl alcohol.

All specimens collected in trawls and observed in camera sled photographs were identified using either general fish guides $[25-27,33,53,54]$ or specialized references $[2-4,6,8-10,18,39,46,59-61,66,67,77]$. All unidentifiable specimens were sent to taxonomic specialists. Although the trawls targeted bottom fishes, several mesopelagic fishes were incidentally taken and these were not included in the analysis.

The camera sled operation was performed by Dr. Barbara Hecker and basic techniques have been described in Hecker $[34,35]$. In all, four camera sled transects were taken, one of which got fouled on rocks and therefore was excluded because it did not cover sufficient bottom area. For comparability, it was important to use the most accurate method of estimating surface area sampled. Techniques outlined in Wakefield and Genin [72] were used to estimate the surface area observed by the camera sled for benthic fishes.

We assumed that there were two types of fishes, those which were smaller and more benthic (eelpouts: Zoarcidae) and those which were larger and more benthopelagic (rattails: Macrouridac). The Wakcficld and Genin [72] technique picks only those portions of the film (i.e. 
camera view) in which each of these two size classes of fishes have a high probability of being seen and identified well. It produces a more conservative, and perhaps for fishes a more accurate, estimate of density.

This analysis basically involved defining taxon-specific lateral and horizontal limits of visibility, based upon the physical set-up of the sled, camera and bottom being surveyed [72]. Based upon an analysis of the films, the probability of detection versus longitudinal distance was plotted for macrourid (figure 2a) and zoarcid (figure 2b) morphotypes. The perpendicular and longitudinal detection functions were then combined to derive the taxonspecific quadrat sizes.

Deep-sea benthic habitats were characterized hy their visual appearance in camera sled photos but could not be assessed from beam trawl samples. The visual appearance of the bottom was subjectively categorized by surface features (mounds, pits, rocks, debris), surface texture or appearance (smooth, lumpy, flocky, etc.), and the presence of invertebrates.

The following approaches were used to compare sampling devices and to determine 'unit samples'. In the main technique, we defined a unit (beam) trawl sample as the mean trawl length $(50 \mathrm{~min})$ and then took the three camera sled films and divided them arbitrarily into $50 \mathrm{~min}$ sections, eliminating any portions which were obviously not focused on the bottom. We also paired 'equivalent' or 'comparable' sections of camera sled tows with lengths, depths, and locations of trawls. To determine how many samples would be necessary to characterize the fish fauna at these depths, we plotted species curves versus the number of samples taken. For beam trawls, we randomly ordered and plotted this relationship four times, and noted that the curve leveled off at around 10 tows [13]. Otter trawls were only used for the summary of all fishes caught. For the camera sled sections, we plotted the three sleds in consecutive order, noling which new species were observed. Again, the curve leveled at around ten 50-minute sections, with each of the slight increases due to rare sightings [13].

Mean densities from both beam trawls and camera sleds, along with their standard deviations and standard errors, were calculated by dividing the number of individuals of each taxon by the area surveyed. These were then plotted as histograms (see figures 3 and 4). To provide a general assessment of the beam trawl and camera sled as a deepsea sampler, we plotted mean overall fish densitics and number of species (both per hectare) and visually com- pared them, along with their standard deviations. The species composition and relative densities were quantitatively compared between combined beam trawl and camera sled section samples, and between pair-by-pair comparable trawls and sled sections, by calculating Percent Similarity Indices (PSI $=$ the sum of the minimum proportions of paired rankings), and non-parametric rank correlation coefficients (Spearman's and Kendall's tau; [43]).

For faunal comparison, an additional 17 beam trawl samples were taken between February 27 and March 3, 1992 from the R/V Point Sur at three sites (figure 1), 16 of which were successful at collecting organisms. Four of the successful samples were from the Farallon Site, four from the Pioneer Site and eight from the Monterey Site, and all were at comparable depths. All trawling was done in the same manner and with the same beam trawl as in the original 1991 survey [56].

In addition, submersible and beam trawl videos and photographs taken during cruise Number $118-42$ on the R/V Atlantis II between 21-30 October, 1988 were used to compare submersible observations with those from both camera sleds and beam trawls in the Monterey area and among all three areas. We used videos and photographs produced from five dives and three camera sled tows at similar depths (1 515-3650 m) in the Monterey Submarine Canyon for qualitative analysis of the fish fauna ([23, 24] for detailed descriptions of these dives and camera tows). Because of the qualitative nature of the videos and stills, we could not convert our observations into densities and report the comparative results as presence or absence of identifiable species. In only one of these dives (number 2122) was bait (albacore Thunnus alalunga) used. Combined with the submersible and camera sled observations, these samples allowed us to make at least a qualitative statement about the comparability of this site with that already studied off the Farallones.

As with camera sled photographs, subjective descriptions of the sea floor and canyon habitats and the presence of epifaunal invertebrates and drift algae from Alvin submersible and camera sled videos and photographs were used to characterize the habitats used by the fish fauna. In addition to characterizing the visual appearance of the soft bottom and its surface texture, in this set of dives rocky outcroppings and canyon walls were commonly noted along with epifaunal invertebrates, such as crinoids, brisingids, holothuroids, cerianthid anemones, sponges, 'worm' tubes, bivalve shells, and bacterial mats. 

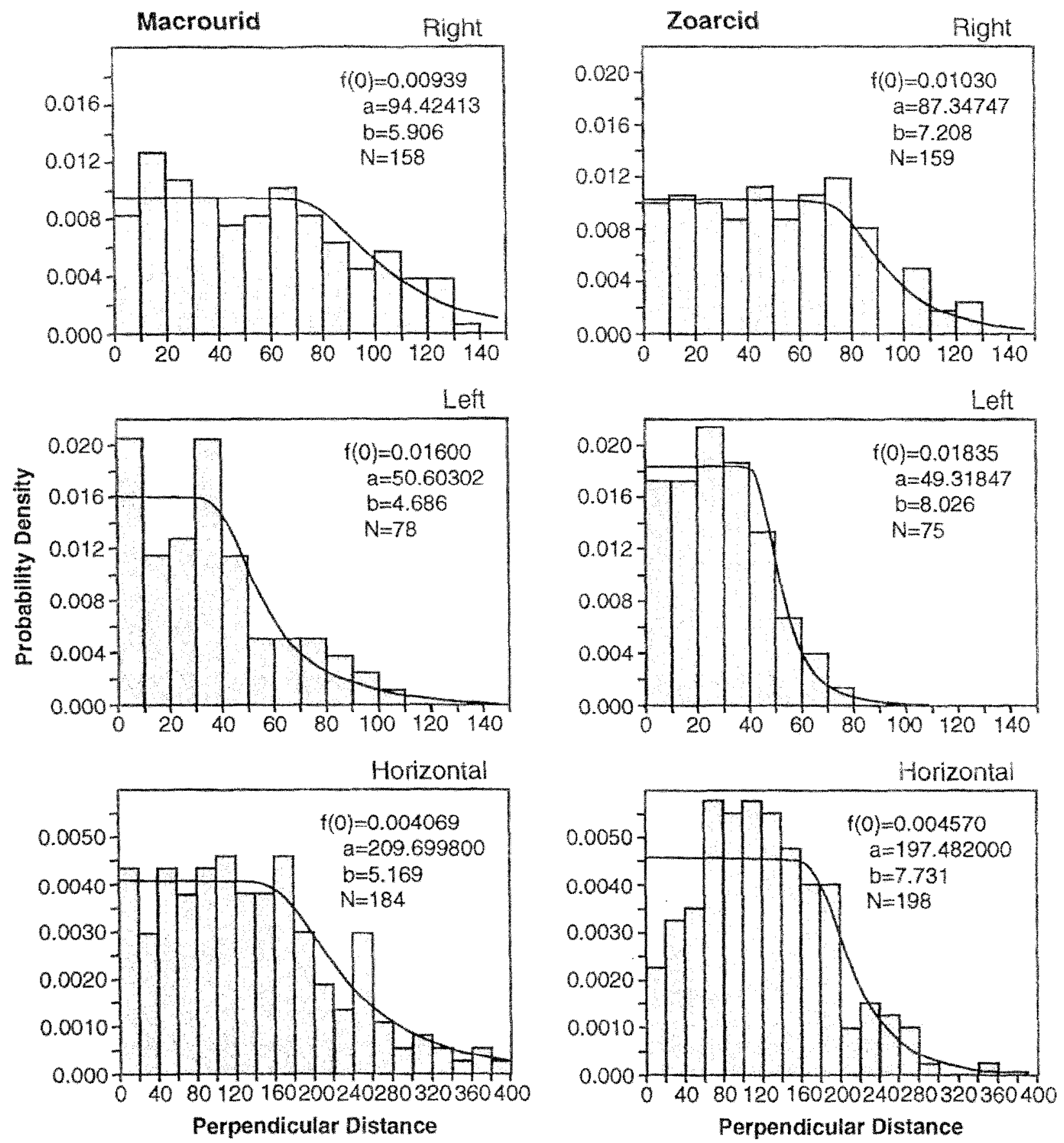

Figure 2. Probability of detection curves [72] for the smaller zoarcid (a) and larger macrourid (b) fishes. Each plot is specinic to a region (right, left, and horizontal) in the Canadian grid, which was used to estimate the area of the photo-quadrat.

\section{RESULTS}

Beam trawl samples in 1991 and 1992 collected at least 11 species of fishes (figure $3 \mathrm{a}$ ) and both the dominant species and species composition were similar between years, with the overall similarity being $54.9 \%$ and significant according to one of the two rank correlation analyses. In 1991, beam trawls collected at least 10 spe- 

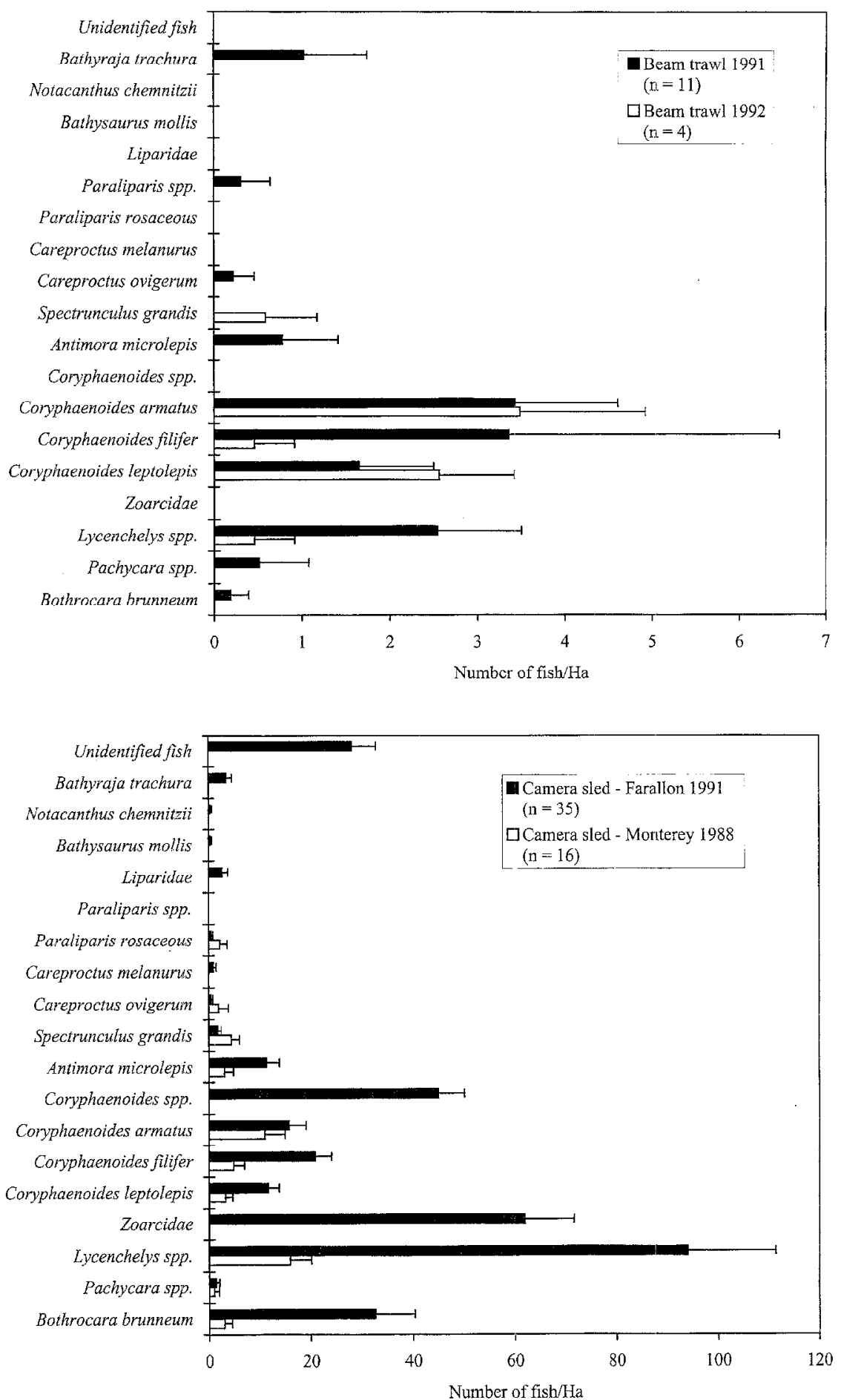

Figure 3. Comparisons of fish density histograms for two sampling techniques, beam trawl (a) and camera sled (b). Beam trawl data were taken from the Farallon Site in 1991 ( 67 fishes) and 1992 ( 14 fishes). Camera sled data were taken from the Farallon Site in 1991 ( 890 fishes) and the Monterey Site in 1988 (55 fishes). Mean densities of the dominant fish taxa (to lowest possible taxonomic level) were calculated as numbers per hectare with standard errors, using individual tows and 35-50 min sections from the beam trawls and camera sleds, respectively. Note that scale of axes differ between plots. Note also that some fishes were only identified to family or genus and unidentified fish were only present in the 1991 camera sled samples. Unidentified fishes were not quantified in the 1988 Monterey samples. 
cies, while in 1992 there were only five. The catches in both years were dominated by the macrourids Coryphaenoides armatus, C. filifer, and C. leptolepis, the zoarcids Lycenchelys spp., Pachycara lepinium, and Bothrocara spp., the morid Antimora microlepis, and the rajid Bathyraja trachura. Several rarer species were also collected.

Camera sleds photographed at least 15 species of fish (figure 3b), with 14 of these seen in 1991 and 10 recorded in the 1988 Monterey Site samples. The dominant fish group in these samples was the zoarcids, led by Lycenchelys spp. (figure 5c) and Bothrocara spp., followed by the three macrourid species found in the beam trawls. Coryphaenoides acrolepis was never collected in the deeper beam trawls, but photographed primarily at the shallow end of one camera sled tow at $1600 \mathrm{~m}$. Several rare species of fish were seen only in the sled photographs, including the notacanthid Notacanthus chemnitzii, synodontid Bathysaurus molits, and the liparidids Paraliparis rosaceus and Careproctus melanurus.

Beam trawl and camera sled section sample comparisons (figures $3 a$ and $b$ ) indicate that dominant fish families appeared to differ in their relative abundances. The trawls collected relatively fewer of the smaller and more demersal zoarcids, photographed in large numbers by the sleds, and more of the larger and more mobile macrourids. More categories of unidentified tish taxa occurred in the camera sled photographs. In addition, the beam trawls collected fewer species (11) than were observed in the camera sleds (15), with the total number of species being 15 , depending upon fulure decisions on the identifications of the Paraliparis, Lycenchelys, and Bothrocara represented in the samples.

When all the data were combined from each technique and compared the species composition between beam trawls and camera sleds, the Percent Similarity Index (PSI) was $50.5 \%$, and both of the non-parametric rank correlation coefficients (tau $=0.568$ and $\left.r_{\mathrm{s}}=0.439\right)$ indicated that this similarity was statistically significant at the 0.05 probability level. However, the pair-by-pair comparison produced a much lower, and presumably insignificant, similarity value (PSI $=32.0 \%$ ). This may indicate that the individual pair-by-pair trawl and camera sled sections were of insufficient length to comparably collect all species common to the assemblage.

The comparative statistics of fish density and species numbers also indicate that the camcra sled provided estimates that were much higher than the trawl samples (figure 3). The mean density of ali fishes in the beam trawls was $14.01(\mathrm{SD}=16.62)$ fish per hectare, a relatively low value, but the high standard deviation indicates high patchiness. Mean densities were much higher in the camera sled photographs than the beam trawls, averaging 207.00 ( SD $=142.70)$ fish per hectare, significantly higher than estimates from beam trawls, but also indicating high patchiness. The camera sleds produced means of 4.57 ( $\mathrm{SD}=1.36)$ tish species per hectare, whereas the beam trawls estimated approximately half as many (2.64. $\mathrm{SD}=2.25$ ).

Based on all sampling tcchniques, there was a minimum total of 15 fish species taken in the area. However, several future taxonomic decisions may increase this number. For example, we may have as many as three species of Lycenchelys (M.E. Anderson, pers. comm.).

Similar species dominated the beam trawl samples taken at the three sites in 1992 (figure 4), even though the number of samples taken in each of these sites was smaller than the cumulative species analysis indicated. In total, all sites produced 8 species. The Monterey Site ( 8 traw! samples) produced 7 species, followed by the Farallon Site ( 4 samples, 6 species), and the Pioneer Site ( 4 samples, 3 species). Even though PSIs ranged from a low value of $43.9 \%$ between the Monterey and Pioneer Sites to $71.7 \%$ between the Farallon and Pioneer Sites, in all 1992 comparisons, the rank correlation coefficients were all statistically significant. However, the Farallon Site samples in 1991 were similar to Pioneer Site samples in 1992, but not to Monterey Site samples in 1992. A new species, the liparidid Acantholiparis spp., was observed at the Monterey Site in 1992 beam trawls.

Using the $\mathrm{D} / \mathrm{S}$ Alvin photographs taken at the Monterey Site in 1988 , the fish fauna was fairly similar to that obtained by the combined beam trawl and camera sled surveys. If only those dives which exceeded $2300 \mathrm{~m}$ are used, a minimum of four species was seen from the submersible. However, if dive $2128(1800-2000 \mathrm{~m})$ is included, the total list is more similar to those seen in figures 3 and 4. During the shallower dive (2122 at $1515 \mathrm{~m}$ ), four species were observed that had not been caught or seen in the deeper beam trawl or camera sled samples, including the squalid shark, Somniosus pacificus, anoplomatid Anoplopoma fimbria, cottid Psychrolutes phrictus, and pleuronectid Embassichthys bathybius, making that dive the onc with the highest number of species. 


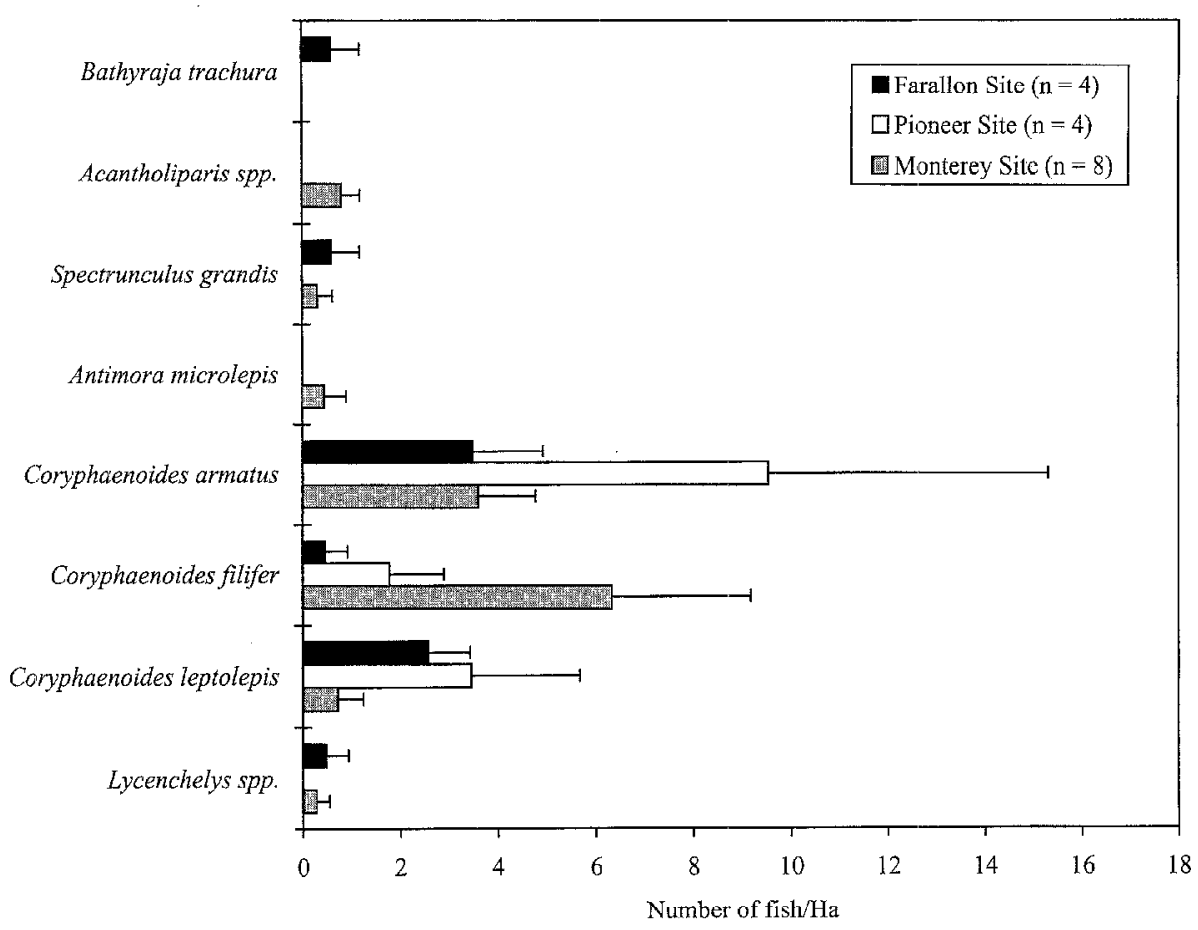

Figure 4. Comparison of fish density histograms for dominant fish taxa at each of the three study sites (Farallon, 14; Pioneer, 16; and Monterey, 47 fishes) taken by beam trawl in 1992. Densities were calculated as in figure 3 legend.

Observations from the camera sled photographs indicated that deep-sea benthic habitats were highly diverse and patchy. Surface features ranged from smooth and virtually featureless to mounded and pitted or rocky. Invertebrates were common and fishes were found associated with all types of habitat (figure 5). Some of the best photographs of fishes also show the range of habitat types. Coryphaenoides filifer ranged from blackish brown to white with black blotches and was seen in a variety of habitats (figures $5 \mathrm{a}, \mathrm{b}, \mathrm{d}$ ). Sea pen beds were common, patchy and could be very dense and included the single sighting of $B$. mollis (figure $5 \mathrm{~d}$ ). Zoarcids were seen in a variety of habitats as well and are shown in an area that would be difficult to categorize because sea pens were present but were not dense. C. leptolepis was clearly identified in a mounded and pitted habitat (figure 5e), similar to the habitat shown in figure 5a. Paraliparis rosaceus was photographed in one of the more featureless habitats with a somewhat flocky appearance (figure 5f). Note that only the eye and mouth of Antimora microlepis was visible in the upper portion of the photograph. This exemplifies the limited nature of deep-sea photographs and the identification of incomplete, dark or cryptic fish images.
Videos and photographs from camera sleds and D/S Alvin dives at the Monterey site demonstrated the additional existence of steep, canyon-wall habitats. However, most of the fishes occurred in similar abundances on the sedimentary sea floor and at the edge of the submarine canyon walls. Several of the Alvin dives involved baited cages, so habitat associations could not be inferred from these.

\section{DISCUSSION}

It is pertinent from the data gathered to compare the advantages and disadvantages of using nets versus photography and personal observations in the deep sea. Among the advantages of using nets such as a beam trawl is that voucher specimens can be obtained, which prove essential for identification of small, difficult or unknown taxa by taxonomists. Trawls also provide specimens which can be used for additional ecological and physiological studies. While not perfect, trawl samples can be used to estimate relative faunal densities, and along with this is accurate biomass and size information. 

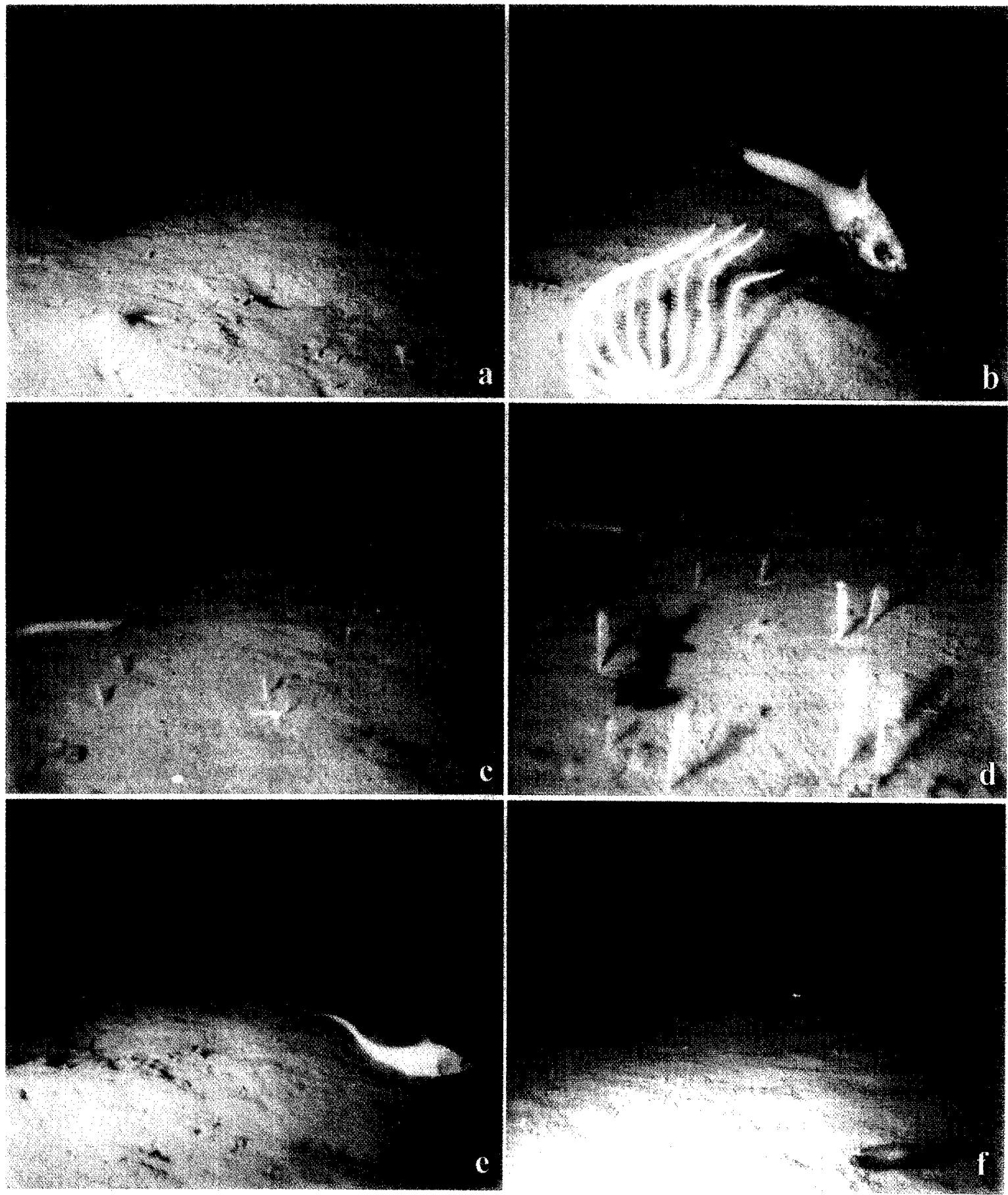

Figure 5. Photographs of several dominant fishes and their typical abiotic and biotic habitat association from the camera sied transects at the CMDA: a) the black morph of Coryphaenoides filifer in an area of high bioturbation (mounds, pits and extruded sediment piles) with a few sea pens at $3085 \mathrm{~m}$; b) the white morph of C. filifer in an area with large sea stars (family Brisingidae) and holothurians (Pannychia moseleyi) at $2086 \mathrm{~m}$; c) Lycenchelys spp. (species of this genus could not be identified because diagnostic characteristics were not visible) in an area with several sea pen species at $2535 \mathrm{~m}$; d) the rare synodontid, Bathysaurus mollis (upper left), among a dense bed of sea pens (Kophobelemnon spp.) and unidentified ophiuroids, with a black morph of $C$. filifer swimming away from the camera, at $3048 \mathrm{~m}$; e) clearest image of $C$. leptolepis in a habitat similar to figure $5 \mathrm{a}$; and f) virtually featureless habitat with Paraliparis rosaceus (lower right) and Antimora microlepis in the upper portion visible as only an eye and a mouth. 
Among the disadvantages of using beam trawls is the inevitable avoidance and escape response of the target organisms, especially the mobile fishes, which cause underestimates of abundance and biomass of the fauna [52]. Also, it is not known whether the trawl was always on the bottom. This type of gear is limited by high relief bottom topography and thus makes area estimates even more difficult. Trawls provide little information on dispersion, behavior, actual species associations, or habitat utilization.

Among the advantages of using camera sled photographic samples is that a relatively continuous record, providing habitat information, is possible. One can often work in high relief areas and observe the larger, more agile, and perhaps rarer fauna. Given that accurate calibration is possible to produce surface area estimates $[1$, $64,72,74]$, camera sled photographs can allow a good estimate of area, from which one can calculate faunal densities accurately and provide useful indices of dispersion patterns.

The highly diverse habitats at the study sites were characterized largely by the presence or absence of invertebrates and their actions [36, 24]. Most of the bottom structure visible, other than rock or debris, could be attributed to excavations of invertebrate infauna (mounds, pits, sediment extrusions, etc.; figures 5a, e, f) ¡23, 24, 34, 35]. In many cases, the habitat structure was the invertebrates themselves, creating relief above the bottom (figures $5 \mathrm{~b}-\mathrm{d}$ ). Sea pen and sea star beds were most notably patchy and none of the larger, identifiable fishes seemed to be associated with any specific habitat or structure. Habitat classification was often difficult and types overlapped (figure 5c). It was also impossible to know if the camera sled was in close proximity to a patch of different habitat (rocks, sea pen bed, etc.). In addition, it was impossible to know if some fishes were attracted or repelled by disturbance or lights produced by the camera sled.

Based on our observations, macrourids and zoarcids appear to be ubiquitous in their distribution and not specifically associated with any of the various habitat types seen at the three study sites. Other species or families were not abundant enough to produce any conclusions about habitat associations. A study specifically designed to test the validity and strength of faunal habitat association or affinity is needed for these remote, deep-sea benthic environments.

Among the disadvantages of deep-sea photography is that no specimens are available for accurate identification, taxonomic work, or voucher collections. Also, without sophisticated measuring devices, size and biomass estimates are impossible. Other limitations include possible photonegative responses [42] and the inability to observe smaller, infaunal organisms, which can often be dredged or scared out of their habitats by nets. Perhaps the most crucial limitation is that the data analysis after-the-fact is very time consuming, and therefore costly. However, the precision may be worth the expense.

Although there might be lack of independence problems associated with subsampling sled samples, the cost-effectiveness and site-specific attributes make it a very attractive option. Also, it is apparent that approximately ten 50 -minute trawls or camera sled samples are sufficient to characterize the fauna of a given location, similar to results presented by Merrett and Domanski [50].

The photographic samples can provide behavioral information $[16,62,63]$, but are unlikely to help understand trophic [11, 16, 21, 48, 57, 73], reproductive [69], or age and growth $[7,40,44,47,75,76]$ information on these deep-sea fishes. This work requires specimens collected during sampling surveys.

The deep-sea demersal fish fauna described here appears to be similar in species composition to the faund of the eastern Pacific [28, 38, 58, 73] and other deep-water ocean sites $[5,29,51,52]$ around the world. Observations (visual, photographic and video) from submersibles and camera sleds appear to include most of the dominant species of fishes, but have the distinct disadvantage of missing or not being able to identify the smaller fishes. Avoidance of the beam trawl can also be a problem. However, trawls collect specimens, allowing for correct identification, even of the smaller fishes. Thus, a combination of all three is probably the most accurate approach to characterizing the fish fauna of a deep-sea area [51]. Certainly, the use of the observational techniques is essential to characterize habitat structures and faunal associations with these habitats. Because much of the habitat is created by the infaunal and epifaunal invertebrate organisms, visual techniques are even more important.

\section{Acknowledgements}

We thank PRC Environmental Management, Inc. for providing funds through the Navy CLEAN Contract No. N62474-88-D-5086 to support the beam trawl and camera sled surveys. We also thank the National Geographic 
Society and the National Science Foundation for providing the $\mathrm{D} / \mathrm{S}$ Alvin and $\mathrm{R} / \mathrm{V}$ Atlantis II for the successful series of dives in the Monterey Submarine Canyon. In addition, the Monterey Bay Aquarium, U.S. Geological Survey, Lamont-Doherty Geological Observatory of Columbia University, and the Monterey Bay Aquarium Research Institute provided support for these dives. We thank the Skippers and Crews of the F/V Morning Star and R/V Wecoma for their support and cooperation in the sampling phases of this project. Cruise leaders Barbara Hecker (Lamont-Doherty) and James Nybakken (MLML) were effective at getting the samples taken.
Likewise, SAIC personnel Chris Christensen and Dan Reifsteck are to be commended for their gear development and their efforts in both the trapping and trawling operations. As usual, the MLML people Frank Roddy, Lisa Smith-Beasley, Erik Cordes, Missy Gibbs, Lisa Weetman, Susan Craig, Anne Summers, and Lara Ferry were immensely helpful. Lynn McMasters created several of the figures. We also thank the National Science Foundation for its Award 9731001 that supported our travel to and participation in the November 1997 workshop on marine benthic habitats and their living resources in Noumea, New Caledonia.

\section{REFERENCES}

[1] Adams P.B., Butler J.L., Baxter C.H., Laidig T.E., Dahlin K.A., Wakefield W.W., Population estimates of Pacific coast groundfishes from video transects and swept-area trawls, Fish. Bull. 93 (1995) 446-455.

[2] Anderson M.E., A new eelpout from the Eastern tropical Pacific Ocean, Bull. Mar. Sci. 32 (1) (1982) 207-212.

[3] Anderson M.E., Review of the eelpout genus Pachycara Zugmayer, 1911 (Teleostei: Zoarcidae), with descriptions of six new species, Proc. Calif. Acad. Sci. 46 (10) (1989) 221-242.

[4] Anderson M.E., Studies on the Zoarcidae (Teleostei: Perciformes) of the southern Hemisphere, III. The Southwestern Pacific, J.L.B. Smith Inst. Ichthyology, Spec. Publ. (50) (1990) $1-17$.

[5] Anderson M.E., Crabtree R.E., Carter H.J., Sulak K.J., Richardson M.D., Distribution of bottom fishes of the Caribbean Sea found below 2000 inelers, Bull. Mar. Sci. 37 (1985) 794 807.

[6] Anderson M.E., Peden A.E., The celpout genus Pachycara (Teleostei: Zoarcidae) in the northeastern Pacific Ocean, with descriptions of two new species, Proc. Calif. Acad. Sci. 46 (3) (1988) 83-94.

[7] Andrews A.H., Cailliet G.M., Coale K.H., Age and growth of the Pacific grenadier (Coryphaenoides acrolepis) with age estimate validation using an improved radiometric ageing technique, Can. J. Fish. Aq. Sci, 56 (1999) 1339-1350

[8] Andriyashev A.P., A review of the genus Lycenchelys Gill (Pisces, Zoarcidae) and related forms in the seas of the USSR and adjacent waters, Trudy Zool. Inst. Akad. Nauk SSSR, XVII: 349-384, Translated from Russian, IPST Cat. No. 765, 605, 608, Israel Program for Scientific Translations, Jerusalem, 1963, Available Nat. Techn. Inf. Serv., Springfield (1955) VA 22151.

[9] Andriyashev A.P., An addition to the review of Lycenchelys Gill, with a description of three new species from the KuriloKamchatkan Trench. Voprosy Ikhtiologii (11):171-180, Translated from Russian, IPST Cat. No. 765, 605, 608, Israel
Program for Scientific Translations, Jerusalem, 1963, Available Nat. Techn. Inf. Serv., Springfield (1958) VA 22151.

[10] Bayliff W.H., Notes on the taxonomy and distribution of certain zoarcid fishes in the northeastern Pacific, Copeia 1959 (1) (1959) $78-80$.

[11] Bergstad O.A., Distribution, population structure, growth and reproduction of the roundnose grenadier Coryphaenvides rupestris (Pisces: Macrouridae) in the deep waters of the Skagerrak, Mar. Biol. 107 (1990) 25-39.

[12] Bianchi G., Demersal assemblages of the continental shelf and upper slope of Angola, Mar. Ecol. Progr. Ser. 81 (1992) 101201.

[13] Cailliet G.M., Wakefield W.W., Moreno G., Andrews A., Rhodes K., The deep-sea fish fauna from the proposed Navy Ocean Disposal Site, using trap, otter and beam trawl, and camera sled samples. Final Report on Navy CLEAN Contract No. N62474-88-D5086, to PRC Environmental Management, Inc., Honolulu, Hawaii and San Francisco, Califomia (1992) $66 \mathrm{p}$.

[14] Christiansen B., A television and photographic survey of megafaunal abundance in central Sognefjorden, western Norway, Sarsia 78 (1993) 1-8.

[15] Cohen D.M., Ten dives of the DSRV Alvin in and near DWD106 Dumpsite, in: Baseline report of the Environmental Conditions in Deepwater Dumpsite 106, NOAA Evaluation Report (1975) 77-1.

[16] Cohen D.M., Swimming performance of the gadoid fish Antimora rostrata at $2400 \mathrm{~m}$, Deep-Sea Res. 24 (1976) 275-277.

[17] Cohen D.M., Haedrich R.L., The fish fauna of the Galapagos thermal vent region, Deep-Sea Res. 30 (4A) (1983) 371-379.

[18] Cohen D.M., Nielsen J.G., Guide to the identification of genera of the fish order Ophidiiformes with a tentative classification of the order, NOAA Technical Report NMFS Circular (1978) (417).

[19] Cohen D.M., Pawson D.L., Observations from the DSRV Alvin on populations of benthic fishes and selected larger 
invertebrates in and near DWQD-106, NOAA Dumpsite Evaluation Report 77-1 (1977) 423-450.

[20] Cohen D.M., Rosenblatt R.H., Haedrich R.L., Identity of thermal vent fishes in the eastern Pacific: an interim report, Biol. Soc. Wash. Bull., 6 (1985) 229-230.

[21] Crabtree R.E., Carter J., Musick J.A., The comparative feeding ecology of temperate and tropical deep-sea fishes from the western North Atlantic, Deep-Sea Res. 38 (10) (1991) 12771298.

[22] Day D.S., Pearcy W.G., Species associations of benthic fishes on the continental shelf and slope off Oregon, J. Fish. Res. Bd. Canada 25 (12) (1968) 2665-2675.

[23] Eittreim S.L., Embley R.W., Normark W.R., Greene H.G., McHugh C.M., Ryan W.B.F., Observations in Monterey Canyon and fan valley using the submersible Alvin and a photographic sled, U.S. Geological Survey Open File Report 89291: 1-17 (1989) 11 figs.

[24] Embley R.W., Eittreim S.L., McHugh C.H., Normark W.R., Rau G.H., Hecker B., DeBevoise A.E., Greene H.G., Ryan W.B.F., Harrold C., Baxter C., Geological setting of chemosynthetic connunities in the Monterey Fan Valley system, Deep-Sea Res. 37 (11) (1990) 1651-1667.

[25] Eschmeyer W.N., Catalog of the Genera of Recent Fishes, Cal. Acad. Sci. (1990) 697 p.

[26] Eschmeyer W.N., Herald E.S., Hammann H., A ficld guide to Pacific coast fishes of North America, Hougton Mifflin Company, Boston (1983) $336 \mathrm{p}$.

[27] Fitch J.E., Lavenberg R.J., Deep-water teleostean fishes of California, Univ. Calif. Press, California Natural History Guides (25) (1968) 155 p.

[28] Gotshall D.W., Dyer R.S., Deepwater demersal fishes observed from the submersible AVALON (DSRV-2) off the Farallon Islands, 24 June 1985, Calif. Dept. Fish and Game, Mar. Res. Tech. Rep. (55) (1987) I-15.

[29] Grassle J.F, Sanders H.L., Hessler R.R., Rowe G.T., McLellan T., Pattern and zonation: a study of the bathyal megafauna using the research submersible Alvin, Deep-Sea Res. 22 (1975) 457-481.

[30] Greene H.G., Geology of the Monterey Bay region, U.S., Geological Survey Open-File Report, No. 77-718 (1977) 347 p.

[31] Greene H.G., Stubblefield W.L., Theberge A.E., Jr. Geology of the Monterey Submarine canyon system and adjacent areas, offshore central California: results of NOAA SeaBeam Survey, descriptive report for the Surveyor cruise, U.S. Geological Survey Open-File Report, No. (1989) 89-221.

[32] Haedrich R.L., Distribution and population ecology, Chapter 3, pages 79-114, in: Randall D.J., Farrell A.P. (Eds.), Deep-sea fishes, Academic Press, San Diego, California (1997) 388 p.

[33] Hart J.L., Pacific fishes of Canada, Fish. Res. Bd. Canada, Bull. (180) (1973), 1-740.

[34] Hecker B., Variation in megafaunal assemblages on the continental margin south of New England, Deep-Sea Res. 37(1) (1990) $37-57$.
[35] Hecker B., Biological and sedimentological investigations of the sea floor at the proposed U.S. Navy Ocean Disposal Sites, July 1991 Survey (R/V Wecorna), megafaunal assemblages, Final Report on Navy CLEAN contract No. N62474-88-D5086, to PRC Environmental Management, Inc., Honolulu, Hawaii and San Francisco, California and Science Applications International Corporation, Woods Hole, Mass. (1992) 66 p. plus A-1-3.

[36] Heezen B.C., Hollister C.D., The Face of the Deep, Oxford Univ. Press, New York (1971) 659 p.

[37] Isaacs, J.D., Schwartzlose R.A., Active animals of the deepsea floor. Sci. Am. 233 (1975) 84-91.

[38] Iwamoto T., Report on the EPA cruise to the Farallon Islands low-level radioactive water disposal site, 123-19 December 1986 (1986) $11 \mathrm{p}$

[39] Iwamoto T., Stein D.L., A systematic review of the rattail fishes (Macrouridae: Gadiformes) from Oregon and adjacent waters, Cal. Acad. Sci., Occasional Papers (111) (1974) 1-79.

[40] Kastelle C.R., Kimura D.K., Nevissi A.E., Gunderson D.R., Using Pb-210/Ra-226 disequilibria for sablefish, Anoplopoma fimbria, agc validation, Fish. Bull. 92 (1994) 292-301.

[41] Koslow J.A., Bulman C.M., Lyle J.M., The mid-slope demersal fish community off southeastern Australia, Deep-Sea Res. I 41 (1) (1994) 113-141.

[42] Koslow J.A., Kloser R., Stanley C.A., Avoidance of a camera system by a deepwater fish, the orange roughy (Hoplostethus atlanticus), Deep-Sea Res. I 42 (2) (1995) 233-244.

[43] Krebs C.J., Ecological Methodology, Harper Collins Publishers, New York (1989) 654 p.

[44] Kulikova C.B., [Growth and age of deep water fishes.] Trudy Inst. Okeanol. Akad. Nauk. 20:347-355 (In Russian; Trans1. by Am. Inst. Biol. Soc. 1959 (1957) 284-290).

[45] Langton R.W., Uzmann J.R., A photographic survey of the megafauna of the central and eastern Gulf of Maine, Fish. Buil. 87 (1989) 945-954.

[46] Lea R.N., Rosenblatt R.H., Occurrence of the family Notacanthidae (Pisces) from marine waters of California, Cal. Fish and Game, 73 (1) (1987) 51-53.

[47] Matsui T., Kato S., Smith S.E., Biology and potential use of Pacific grenadier, Coryphaenoides acrolepis, off California, Mar. Fish. Rev. 52 (3) (1990) 1-17.

[48] Mauchline J., Gordon J.D.M., Foraging strategies of deep-sea fish, Mar. Ecol. Progr. Ser. 27 (1986) 227-238.

[49] Merrett N.R., A zone of faunal change in assemblages of abyssal demersal fish in the eastern North Atlantic: a response to seasonality in procluction? Biol. Oceanogr. 5 (1987) 137-151.

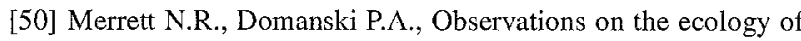
deep-sea bottom-living fishes collected off northwest Africa: II, The Moroccan slope $\left(27^{\circ-} 34^{\circ} \mathrm{N}\right)$, with special reference to Synaphobranchus kaupi, Biol. Oceanogr. 3 (1985) 349-399.

[51] Merrett N.R., Gordon J.D.M., Stehmann M., Haedrich R.L., Deep demersal fish assemblage structure in the Porcupine Seabight (Eastern North Atlantic): slope sampling by three diffe- 
rent trawls compared, J. Mar. Biol. Ass. L.K. 71 (1991) 329 358.

[52] Merrett N.R., Haedrich R.L., Deep-sea demersal fish and fisheries, Chapman and Hall, London (1997) 282 p.

[53] Miller D.J., Lea R.N., Guide to the coastal marine fishes of California, Calif. Fish and Game, Fish Bull. (157) (1972) 1-235.

[54] Nelson J.S., Fishes of the world, 2nd Ed., John Wiley and Sons (1984) $523 \mathrm{p}$.

[55] Nybakken J., Smith-Beasley L., Summers A., Craig S., Weetman L., Invertebrate megafauna collected from the proposed U.S. Navy Ocean Disposal Site as determined from beam and otter trawls and camera sled samples. Final Report on Navy CLEAN Contract No. N62474-88-D-1991, for PRC Environmental Management, Inc., Honolulu, Hawaii (1992a) 56 p.

[56] Nybakken J., Moreno G., Smith-Beasley L., Summers A., Craig S., Weetman L., Supplementary Report for Navy CLEAN Contract No. N62474-88-D-1991, for PRC Environmental Management, Inc., Honolulu, Hawaii (1992b) 32 p.

[57] Pearcy W.G., Ambler J.W., Food habits ol deep-sed macrourid fishes off the Oregon coast, Deep-Sea Res. 21 (1974) 745759.

[58] Pearcy W.G., Stein D.L., Carney R.S., The deep sea benthic fish fauna of the northeastern Pacific Ocean on Cascadia and Tufts abyssal plains and adjoining continental slopes, Biol. Oceanogr. 1 (4) (1982) 375-428.

[59] Peden A.E., Two new specimens of the notacanthid fish Macdonaldia challengeri in the eastern North Pacific Ocean. J. Fish. Res. Bd. Canada 25(1) (1968) 181-188.

[60] Peden A.E., Records of eelpouts of the genus Lycenchelys and Embryx from the Northeastern Pacific Ocean, Syesis 6 (1973) $115-120$

[61] Peden A.E., Occurrence of the eelpout, Bothrocara pusillum off British Columbia, Syesis 12 (1979) 183-184.

[62] Priede 1.G., Bagley P.M., Armstrong J.D., Smithi K.L. Jr., Merrett N.R., Direct measurement of active dispersal of foodfalls by deep-sea demersal fishes, Nature 351 (1991) 647-649.

[63] Priede I.G., Smith K.L. Jr., Armstrong J.D., Foraging behavior of abyssal grenadier fish: inferences from acoustic tagging and tracking in the North Pacific Ocean, Deep-Sea Res. 37 (1) (1990) 81-101.

[64] Russell R.A., Serafy J., Deep-sea demersal fish density estimates compared from simultaneous net catches and photography, Occanol. Acta 9 (4) (1986) 503-508.
65] Schneider D.C., Gagnon J.-M., Gilkinson K.D., Patchiness of epibenthic megafauna on the outer Grant Banks of Newfoundlarid, Mar. Ecol. Prog. Ser. 39 (1987) 1-13.

[66] Small G.J., A review of the bathyal fish genus Antimora (Moridae: Gadiformes), Proc. Calif. Acad. Sci. 42 (13) (1981) 342-348.

[67] Stein D.L., A review of the deepwater Liparidae (Pisces) from the coast of Oregon and adjacent waters, Calif. Acad. Sci., Occasional Papers (127) (1979) 1-55.

[68] Stein D.L., Towing large nets by single warp at abyssal depths: methods and biological results, Deep-Sea Res. 32 (2) (1985) 183-200.

[69] Stein D.L., Pearcy W.G., Aspects of reproduction, early life history, and biology of macrourid fishes off Oregon, USA. Deep-Sea Res. 29 (11A) (1982) 1313-1329.

[70] Uzmann J.R., Cooper R.A., Theroux R.B., Wigley R.L., Synoptic comparison of three sampling techniques for estimating abundance and distribution of selected megafauna: submersible VS camera sled VS otter traw1. Mar. Fish. Rev. 39 (12) (1977) 11-19.

[71] Wakefield W.W., Patterns in the distribution of demersal fishes on the upper Continental Slope off Central California with stidies on the role of ontogenetic vertical migration in particle flux. PhD Thesis, Scripps Inst. Oceanogr. Univ. Calif. San Diego (1990) $280 \mathrm{p}$.

[72] Wakefield W.W., Genin A., The use of a Canadian (perspective) grid in deep-sea photography, Deep-Sea Res. 34 (3) (1987) 469-478

[73] Wakefield W.W., Smith K.L., Jr. Ontogenetic vertical migration in Sebastolobus altivelis as a mechanism for transport of particulate organic matter at continental slope depths, Limnol. Oceanogr. 35 (6) (1990) 1314-1328.

[74] Wakefield W.W., Smithey W.M., Two camera sleds for quantitative studies of deep-sea megafauna, Scripps Inst. Oceanogr. (1989) Ref. SIO 89-14.

[75] Wilson R.R., A comparison of ages estimated by the polarized light method with ages estimated by vertebrae in females of Coryphaenoides acrolepis (Pisces: Macrouridae), Deep-Sea Res. 29 (11A) (1982) 1373-1379.

[76] Wilson R.R., Jr. Analysis of growth zones and microstructure in otoliths of two macrourids from the North Pacific abyss, Envir. Biol. Fish. 21 (4) (1988) 251-261.

[77] Zorzi G.D., Anderson M.E., Records of the deep-sea skates, Raja (Amblyraja) badia Garman, 1899 and Bathyraja abyssicola (Gilbert, 1896) in the eastern North Pacific, with a new key to California skates, Calif. Fish and Game 74 (2) (1988) 87-105. 